\title{
Ampulla of Vater Gangliocytic Paraganglioma
}

National Cancer Institute

\section{Source}

National Cancer Institute. Ampulla of Vater Gangliocytic Paraganglioma. NCI Thesaurus.

Code $C 95989$.

An extra-adrenal parag ang lioma that arises from the ampulla of Vater and the

periampullary region. It consists of a mixture of neuroendocrine cells, Schwann-like cells, and gang lion cells. 